\title{
Nano-Based Theranostic Tools for the Detection and Elimination of Senescent Cells
}

\author{
Jagoda Adamczyk-Grochala *(D) and Anna Lewinska * (D) \\ Department of Biotechnology, Institute of Biology and Biotechnology, University of Rzeszow, Pigonia 1, \\ 35-310 Rzeszow, Poland \\ * Correspondence: ag1jagoda@gmail.com (J.A.-G.); alewinska@o2.pl (A.L.); Tel.: +48-17-851-85-20 (J.A.-G.); \\ +48-17-851-86-09 (A.L.)
}

Received: 18 November 2020; Accepted: 7 December 2020; Published: 10 December 2020

\begin{abstract}
The progressive accumulation of apoptosis-resistant and secretory active senescent cells (SCs) in animal and human aged tissues may limit lifespan and healthspan and lead to age-related diseases such as cancer, neurodegenerative disorders, and metabolic syndrome. Thus, SCs are suggested targets in anti-aging therapy. In the last two decades, a number of nanomaterials have gained much attention as innovative tools in theranostic applications due to their unique properties improving target visualization, drug and gene delivery, controlled drug release, effective diagnosis, and successful therapy. Although the healthcare industry has focused on a plethora of applications of nanomaterials, it remains elusive how nanomaterials may modulate cellular senescence, a hallmark of aging. In this review paper, we consider novel nanotechnology-based strategies for healthspan promotion and the prevention of age-related dysfunctions that are based on the delivery of therapeutic compounds capable to preferentially killing SCs (nano-senolytics) and/or modulating a proinflammatory secretome (nano-senomorphics/nano-senostatics). Recent examples of SC-targeted nanomaterials and the mechanisms underlying different aspects of the nanomaterial-mediated senolysis are presented and discussed.
\end{abstract}

Keywords: nanomaterials; cellular senescence; senotherapy; senolytics; nanotherapeuticmediated senolysis

\section{Cellular Senescence}

Cellular senescence (CS) is characterized by a state of permanent cell growth arrest with altered metabolic features (e.g., affected glycolysis, mitochondrial function, and autophagic flux), modified protein secretion, and biomolecular damage that occurs in response to stressful stimuli [1,2]. CS was originally described in 1961 by Hayflick and colleagues, who observed that normal diploid embryonic fibroblasts had a limited ability to proliferate in an in vitro culture [3]. Based on these results, Hayflick coined the term replicative senescence to describe this phenomenon. Subsequently, progressive telomere shortening promoting DNA damage response (DDR) has been recognized as one of the major determinants of replicative senescence $[4,5]$. Later, the presence of senescent cells (SCs) in aging tissues that linked cellular senescence with organismal aging was documented [6]. Cells can also prematurely activate the senescence program upon treatment with stress stimuli such as UV radiation, oxidants, or DNA-damaging agents [7,8]. This process is known as stress-induced premature senescence (SIPS) [9]. Moreover, the expression of oncogenes could trigger senescence prematurely, in a process called oncogene-induced senescence (OIS) [10]. Cellular senescence may be considered as a tumor suppression mechanism by blocking the proliferation and division of cells with unrepaired DNA damage to prevent their stepwise malignant propagation [11]. However, it has also been demonstrated that cellular senescence may participate in other physiological processes such as specific tissue 
remodeling (so-called developmentally-programmed senescence) that acts in a damage-independent manner during embryonic development and wound healing in adulthood [12,13]. Despite the protective role of cellular senescence during stress-induced cellular responses, it is commonly accepted that CS may promote aging and contribute to the development of age-related diseases. Namely, it has been revealed that diverse pathological conditions associated with accelerated aging such as cancer, neurodegenerative diseases, cardiovascular disorders, and progeroid and metabolic syndromes are accompanied by the accumulation of SCs and cellular senescence may be a causative factor for the progression of age-related pathologies [14-19].

Many different molecular pathways have been proven to contribute to cellular senescence [20,21]. However, one of common features of all SCs is irreversible cell-cycle arrest regulated by p53/p21 WAF1/Cip1 and $\mathrm{p} 16^{\mathrm{INK} 4 \mathrm{~A}} / \mathrm{RB}$ (retinoblastoma) tumor-suppressor pathways, which can interact with each other or act independently [2]. Unlike quiescent cells (the cells at the G0 phase) or terminally-differentiated cells, SCs do not respond to growth and mitogenic stimuli, thus they are irreversibly withdrawn from the cell cycle [17,22]. Two cell-cycle inhibitors that are often overexpressed in SCs, namely p21 WAF1/Cip1 (encoded by CDKN1a gene) and $\mathrm{p} 16^{\mathrm{INK} 4 \mathrm{~A}}$ (encoded by CDKN2a gene) are crucial mediators of senescence. Accumulation of these cyclin-dependent kinase inhibitors (CDKI) resulted in permanent activation of RB family proteins, inhibition of E2F family transcription factor activity, and finally cell-cycle arrest [20].

SCs display common features such as granularity, increased activity of lysosomal senescence-associated $\beta$-galactosidase (SA- $\beta$-gal), lipofuscin accumulation, exclusion of proliferative markers, formation of senescence-associated heterochromatin foci (SAHF), and persistent expression of proteins that participate in DDR (Figure 1) [23-25]. Moreover, SCs are characterized by senescence-associated secretory phenotype (SASP) $[26,27]$. The SASP entails secretion of numerous molecules, such as inflammatory chemokines (e.g., MCP-1, MIP $1 \alpha$, and CCL-16) and cytokines (e.g., IL-6 and IL-8), growth factors (e.g., IGF-1 and EGF) and angiogenic factors/regulators, miRNAs, proteases, and damage-associated molecular patterns (DAMPs), which can induce changes in neighboring cells via both paracrine and autocrine mechanisms [28-31]. SASP may have both beneficial and pathological functions. First, these factors are suggested to regulate immune clearance of SCs to prevent fibrosis and promote tissue regeneration $[1,32,33]$. Contrariwise, SASP factors can induce the development of secondary senescence within non-senescent nearby cells [34]. In addition, the SASP is responsible for promotion of low-grade chronic inflammation. This malfunction can alter the tissue microenvironment, which can also stimulate neoplastic cell growth, tumor metastasis, and angiogenesis [35].

A recently-proposed strategy to delay symptoms of aging is the suppression of SASP components [36]. Notably, compounds that interfere with the pathways involved in SASP regulation are the most effective. These include nuclear factor (NF)- $\mathrm{KB}$, Janus kinase (JAK)/signal transducer and activator of transcription (STAT), mitogen-activated protein kinase (MAPK), and mammalian target of rapamycin (mTOR) pathways [37]. For example, various drugs have been shown to lower production or secretion of SASP factors. Simvastatin decreases production of interleukins IL-6 and IL-8 in vitro [38]. Natural compounds such as flavonoids have also been documented to impair the secretory phenotype in SCs [39]. Importantly, SASP is not the only mechanism by which SCs modulate their neighboring cells. For example, it has been shown that OIS is accompanied by a dynamic fluctuation of NOTCH1 activity [40], reactive oxygen species (ROS) production [41], or by release of exosomes [42]. Apart from irreversible withdrawal from the cell cycle and SASP, another feature of SCs is their resistance to apoptosis through the multilevel regulated pro-survival senescent cell anti-apoptotic pathways (SCAPs) such as p53/p21/serpins, BCL-2/Bcl- $\mathrm{X}_{\mathrm{L}}$, PI3K/AKT/ceramide signaling, the hypoxia-inducible factor (HIF-1 $\alpha$ ) pathway, or HSP90-dependent networks [24,30,43]. 


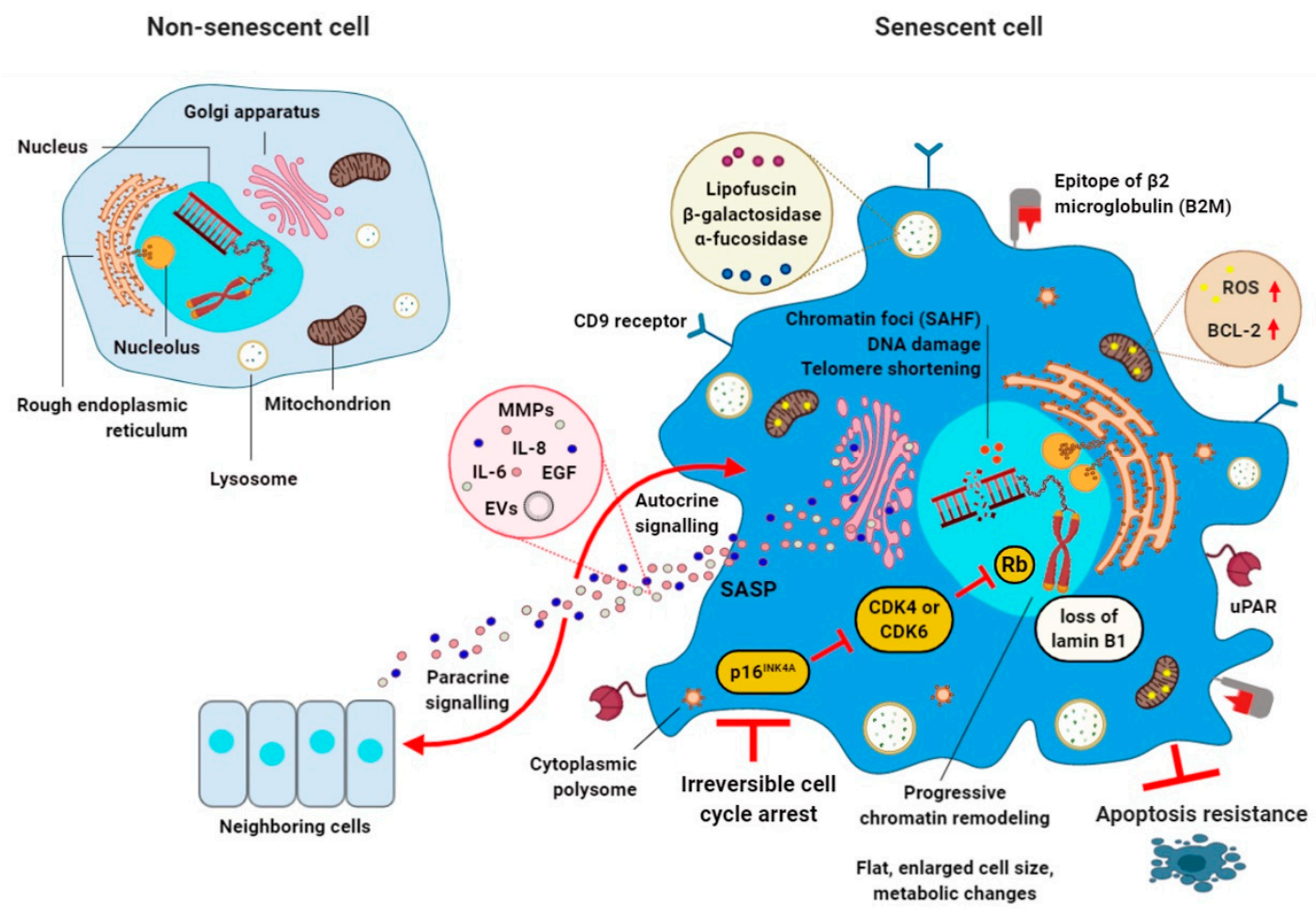

Figure 1. Biomarkers of cellular senescence. Senescent cell (right) is characterized by irreversible cell cycle arrest induced by various stressors (e.g., DNA damage or telomere shortening). Classical features of senescent cells include flat and enlarged cell size, elevated expression of cell cycle inhibitors (such as $\mathrm{p} 16^{\mathrm{INK} 4 \mathrm{~A}}$ or $\mathrm{p} 21^{\mathrm{Cip} 1}$ ), increased nucleus size and multiple nucleoli, lysosomes overexpressing $\beta$-galactosidase, $\alpha$-fucosidase, and lipofuscin, chromatin reorganization based on senescence-associated heterochromatic foci (SAHF) and loss of lamin B1, senescence-associated ribosome biogenesis defects (e.g., "free" cytoplasmic polysomes with ribosomes), the overexpression of anti-apoptotic Bcl-2 family members, reactive oxygen species (ROS) production in mitochondria, and expression of cell surface markers such as CD9 receptor, urokinase-type plasminogen activator receptor (UPAR), and epitope of $\beta 2$ microglobulin (B2M). A characteristic key feature of cellular senescence is also the manifestation of the senescence-associated secretory phenotype (SASP) via the Golgi apparatus. SASP mediates the autocrine/paracrine activities of senescent cells by the secretion of matrix metalloproteinases (MMPs) such as MMP-3 and MMP-9, growth factors (e.g., epidermal growth factor (EGF)), cytokines and chemokines (e.g., IL-6 and IL-8), miRNAs, activins, and inhibins, lipids (e.g., ceramides), as well as exosome-like small extracellular vesicles (EVs). SASP can modify the microenvironment of senescent cells (SCs) and directly affects neighboring cells. A non-senescent cell is also presented (left).

\section{Nano-Based Delivery Systems for Diagnostic and Therapeutic Purposes}

The applications of nanotechnology to medicine provide an opportunity to improve the safety, efficiency, and sensitivity of conventional medical therapeutics [44]. A nano-based drug delivery system relies on the use of nanostructures and nanomaterials for targeted transport of a therapeutic or diagnostic molecule and for its release in controlled manner [45,46]. In addition, the use of large-size structures in drug delivery is challenging, because of their poor bioavailability and stability, undesirable effects, limited targeted drug delivery, and therapy efficiency [47]. Recently, several approaches to drug delivery have been proposed to minimize these limitations by the development and production of smart nanomaterials. Nanomaterials have attracted widespread attention due to their unique properties such as size (100 nanometers or smaller in at least one dimension), shape, surface area, permeability, and various mechanical, magnetic, optical, and electronic properties [48-51]. Nanomaterial properties are significant in determining their important pharmacokinetics criteria, such as adsorption, distribution, accumulation, cellular uptake, and excretion mechanisms [52]. Uptake of nano-sized materials by 
cellular systems may occur via four different basic endocytic mechanisms, namely phagocytosis, macropinocytosis, clathrin-mediated endocytosis, and caveolae-mediated endocytosis [53]. Among the most-often-used nano-sized materials are nanoparticles (NPs), polymers, dendrimers, micelles, liposomes, carbon nanotubes, and fullerenes [52,54]. Moreover, an interesting idea in nanomedical approaches may be the design of multifunctional nanomaterial complexes able to carry out intracellular delivery of one or several cargos, such as diagnostic, imaging, or therapeutic molecules to specific locations in the body (e.g., cells, tissues, or organs) (Figure 2). Such conjugates, upon synthesis, coating, and functionalization, can integrate various functionalities [52,55]. Of note, surface functionalization and coating of nanostructures with various substances such as polymers [56,57], antibodies [58], peptides [59], or surfactants [60] may improve their biocompatibility and limit their immunogenicity. Polyethylene glycol (PEG)-coating of nanostructures (PEGylation) is one of the commonly-used chemical modifications, which may also affect the bioavailability of nano-sized materials [61]. The combination of imaging and therapeutic compounds within a single nanostructure complex may yield a theranostic nanodevice for improved diagnosis and therapy of various diseases such as cancer [62,63]. In addition, nanoformulations for cancer theranostics have been used for targeted drug delivery to solid tumors at relatively high concentrations with minimal toxic effects on surrounding normal cells or tissues $[64,65]$.

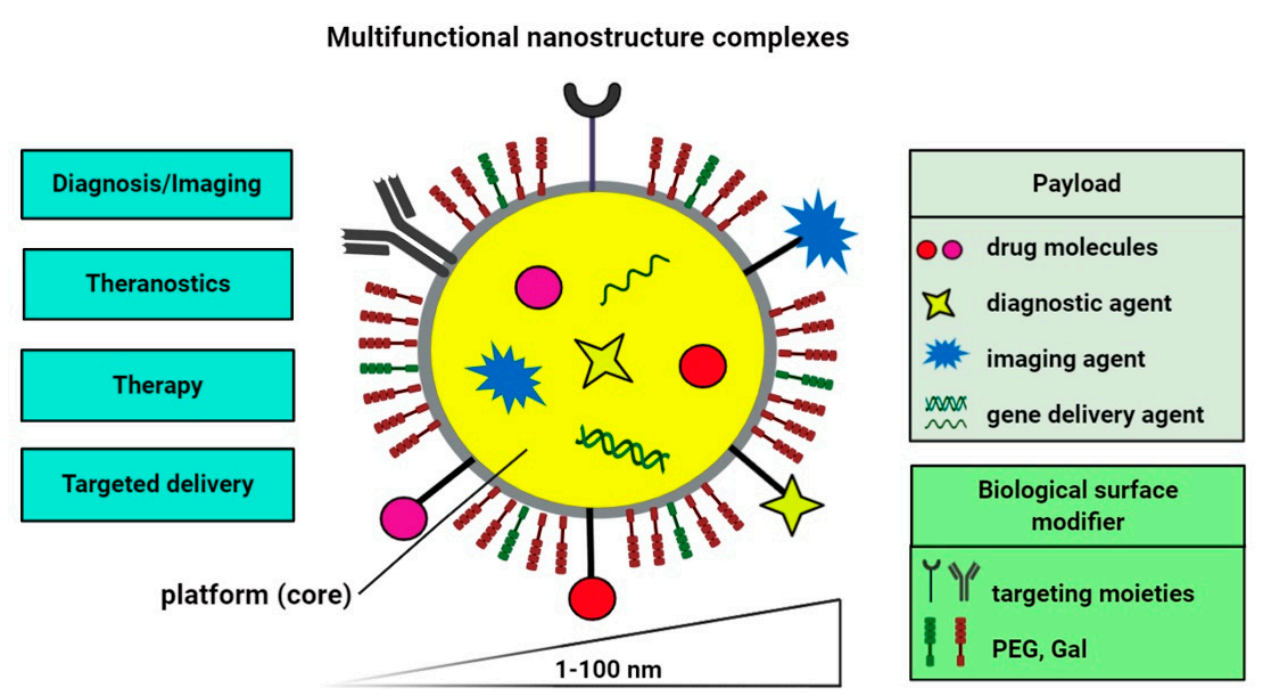

Figure 2. Schematic illustration of nanostructure-based multifunctional complexes. Cargos such as diagnostic probes (e.g., fluorescent or chromogenic dyes, radiotracers, or contrast agents), therapeutic agents (e.g., drugs, siRNA, natural compounds, or chemotherapeutics), surface coating (e.g., PEG, Gal, or mesoporous silica) and targeting ligands (e.g., antibodies or aptamers) can be attached/encapsulated to nanostructures using chemistry and surface modification methods. PEG, polyethylene glycol; Gal, galacto-oligosaccharides.

The use of a nano-based drug delivery system is a rapidly-developing branch of nanomedicine where materials in the nanoscale range are employed to serve as diagnostic and therapeutic tools that may offer multiple benefits in treating human diseases [66]. One of the uses of nanocarriers as drug delivery systems is nano-encapsulation, conjugation, and site-specific transport of therapeutic agents or natural substances for therapeutic purposes [46]. For example, the nucleolin-targeting AS1411 aptamer-decorated niosomes can both effectively recognize cancer cells and deliver the nucleolipidic anticancer drugs that in turn promote antiproliferative effects against human cervical cancer cells [67]. Moreover, the efficiency of natural bioactive compounds, such as quercetin, curcumin, resveratrol, and berberine has been significantly improved by the use of nano-based drug delivery systems [46,68-72]. The properties of nanoscale-sized materials also often differ significantly from those of the same materials at large scales. Hence, nanotechnology has been used to improve the uptake of small agents [46,52]. Moreover, the small size of these agents may enable them to overcome various 
anatomical and physiological barriers which may improve nanodrug mobility and diffusivity to specific body parts $[46,73]$. For example, it has been shown that transferrin-containing gold nanoparticles have increased ability to cross the blood-brain barrier through transcytosis in vivo [74]. In addition, nanosized materials loaded with poorly-water-soluble and chemically-unstable compounds such as quercetin may improve their bioavailability and promote targeted delivery [75]. For example, a six-fold increase in bioavailability of thymoquinone (bioactive compound isolated from Nigella sativa) has been shown after its encapsulation in a lipid nanocarrier in comparison with the unmodified plant-derived compound. The combined use of lipid nanocarrier with thymoquinone increased the pharmacokinetic properties of the bioactive product resulting in better therapeutic effects [76]. Nanotechnology-based drug delivery systems may also protect drugs from the degradation in the gastrointestinal tract and bypass the liver first-pass metabolism, increasing lymphatic absorption and improving drug solubility. Moreover, drugs encapsulated in nano-structures have prolonged circulation time, reduced toxicity, decreased immunogenicity, and increased efficacy $[46,77,78]$.

It is important to mention that stimuli-responsive nanocarriers (also called stimuli-triggered drug delivery) that provide a drug in a time-dependent and concentration-controlled manner can be sensitive to microenvironmental changes and various parameters, namely enzyme concentration, hypoxia, $\mathrm{pH}$, heat, light or electronic pulses, magnetism, temperature and others [79]. For instance, stable at physiological $\mathrm{pH}, \mathrm{pH}$-responsive nanocarriers are promising agents for specific drug delivery to acidic diseased tissues, such as cancer [80]. pH-sensitive controlled release of doxorubicin from doxorubicin-encapsulated nanoparticles has been revealed to result in apoptosis in MCF-7 breast-cancer cells [81]. pH-sensitive nanoparticles loaded with the chemotherapeutic agent are also considered as non-toxic to normal tissues [82]. Recently, several nanocarriers have been proposed for efficient targeting of SCs in vitro and in vivo [83]. The most frequently-used method to detect SCs in vitro and in vivo is the evaluation of the senescence-associated $\beta$-galactosidase activity [84]. It was shown that nanoparticles coated with a substrate for SA- $\beta$-gal and encapsulated with cytotoxic drugs, small molecules, or probes were able to target cargo release mediated by increased SA- $\beta$-gal activity in SCs (Figure 3) $[83,85]$. Molecules that have been developed and designed to detect and visualize SCs are called senoprobes [55]. Importantly, the coated nanostructures are activated only in SCs, where the coating is digested and the cytotoxic drugs/senolytics can be released into the cytoplasm to induce apoptotic cell death that promotes healthspan and extends lifespan in mouse aging models $[83,86]$.

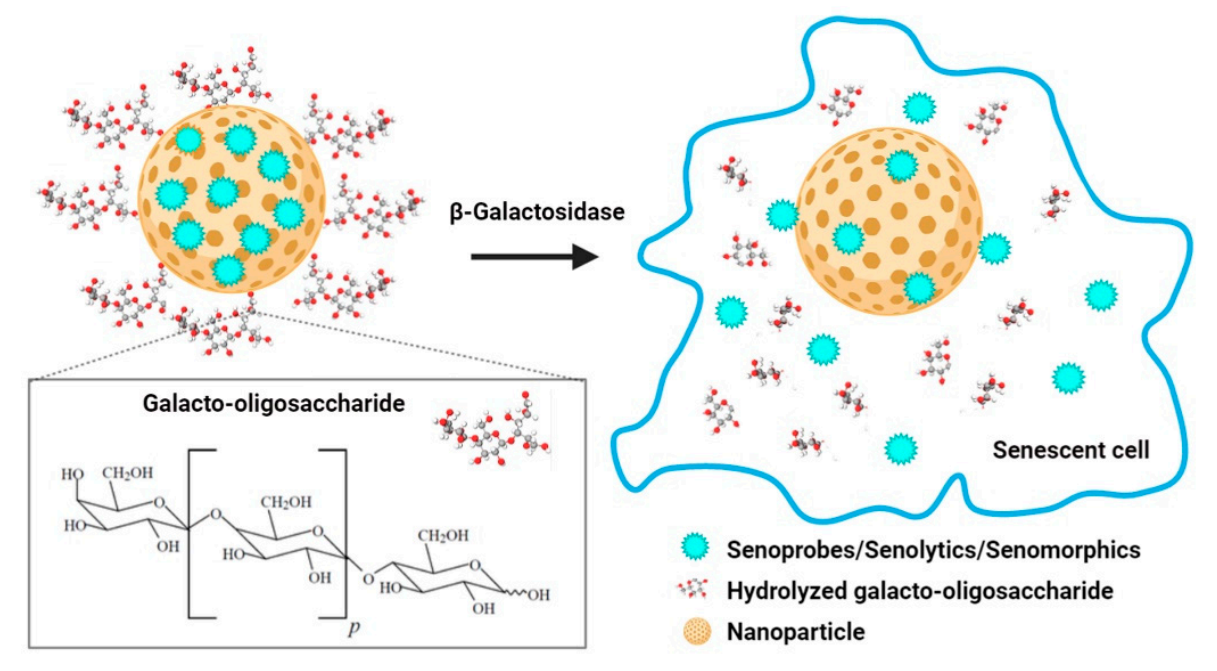

Figure 3. Nanoparticles capped with galacto-oligosaccharide and loaded with senoprobes, senolytics, and/or senomorphics. Cargos can be preferentially released and activated in senescent cells with high activity of SA- $\beta$-galactosidase that is based on SA- $\beta$-galactosidase-mediated hydrolysis of an oligosaccharide coat. 


\section{Senolytics and Senotherapy}

As cellular senescence is an important contributor to aging and age-related disorders, new approaches are required to postpone/prevent detrimental effects mediated by dysfunctional SCs. It has been shown that the selective elimination of SCs is able to attenuate numerous aging-related disorders and extend mouse longevity $[87,88]$. For instance, in progeroid BubR1 (BubR1 ${ }^{\mathrm{H} / \mathrm{H}}$ ) mouse model, the selective eradication of SCs reduces age-related disorders, in a process termed senolysis [88]. It has been shown that removing senescent cells from tissues might inhibit cancer formation in mice suggesting that senolysis in older patients may have healthspan benefits [87]. Senolytic drugs and novel galacto-oligosaccharide-coated nanomaterials with toxic cargos can be considered to target SCs. Senolytic compounds are able to selectively kill SCs, whereas senomorphic compounds are able to diminish SASP $[15,43,88,89]$. It should be pointed out that senolytics must be precisely targeted to eliminate SCs without affecting normal neighboring cells [30].

Bioinformatics approaches based on RNA and protein expression profiles of senescent versus non-senescent cells have been used for identification of SCAPs. Key pro-survival proteins were recognized as potential targets for senotherapy. It is important to note that inhibition of pro-survival pathways and a decrease in the expression of SCAPs may promote death of SCs [43,90-92]. Selected drugs and small molecules from chemical libraries were found to interfere with key components of pro-survival pathways in senescent cells and were considered as first-generation senolytics [24]. Until now, several classes of first-generation senolytics such as natural compounds (e.g., fisetin, quercetin, and piperlongumine), a pan-receptor tyrosine kinase inhibitor dasatinib, HSP90 inhibitors (e.g., geldanamycin, 17-AAG, and 17-DMAG), and Bcl-2 family inhibitors (e.g., navitoclax, ABT-737, A1331852, and UBX1967) have been described [24,43,86,90-99]. Targeting SCAPs in culture in vitro using senolytics may result in apoptosis of some SCs. For example, it has been documented that a combination of drugs with senolytic activity, namely dasatinib (a tyrosine kinase inhibitor) and quercetin (a flavonoid with estrogenic activity) eliminates SCs in human and murine cultured cells in vitro and in vivo $[90,93]$. In addition, this combined treatment significantly improves physiological function and increases lifespan in prematurely-aged mice [90,94-96]. Another agent having senotherapeutic activity is a naturally-occurring flavonoid with low toxicity, fisetin. It has been shown that treatment of old and progeroid mice with fisetin reduces some senescence markers in multiple tissues and extends animal lifespan $[97,98]$. Moreover, fisetin preferentially induces apoptosis in senescent human umbilical vein endothelial cells [97]. It has been shown that a natural product, piperlongumine is also a senolytic agent and preferentially induces apoptosis in oncogene-induced senescent human fibroblast cells [99]. In addition, the senolytic potential of curcumin analog EF24 (a synthetic analog of natural anti-aging compound) in vitro has been reported that was achieved by apoptosis induction in SCs in an ROS-independent manner, and enhanced proteasome mediated-degradation of the Bcl-2 anti-apoptotic protein [100]. Panobinostat, a histone deacetylase inhibitor, also has post-chemotherapy senolytic activity in senescent cancer cells [101]. It has been shown that panobinostat is able to increase caspase 3/7 activity and decrease the expression of anti-apoptotic proteins leading to clearance of SCs, which accumulate after anticancer drug treatment. Another approach to removing SCs from aged mice is targeting the pathways involved in senescence such as the FOXO-p53 axis. Activated FOXO4 transcription factor can induce cellular senescence by interacting with $\mathrm{p} 53$, which leads to upregulation of the transcription of a major regulator of senescence, p21. A novel FOXO4-interacting peptide disturbs the FOXO4 communication with p53 and also can induce apoptosis in both prematurelyand naturally-aging mice. Treatment with FOXO4-peptide can enhance health and lifespan in old mice [102]. Recently, several compounds targeting the chaperone protein HSP90, namely 17-AAG (tanespimycin), geldanamycin, and 17-DMAG (alvespimycin) have been demonstrated to be effective in inducing apoptosis in senescent murine and human cells [43,103]. Interestingly, the first in-human pilot study (14 patients) demonstrated that dasatinib and quercetin can eliminate SCs in patients with age-related chronic lung disease (idiopathic pulmonary fibrosis), reduce inflammation, and limit frailty [93]. More recently, senolytic chimeric antigen receptor (CAR) T cells were designed and 
their efficacy in eliminating of SCs expressing urokinase-type plasminogen activator receptor (uPAR) in vitro and in vivo systems was documented [104]. It has been shown that uPAR-specific CAR T cells may preferentially eradicate SCs in a number of experimental models of senescence [104]. Moreover, BET-family protein degrader (BETd) has been tested for a potential senolytic activity in obesity-induced hepatocellular carcinoma mouse model [105]. It has been reported that BETd may induce senolysis by targeting non-homologous end joining (NHEJ) and autophagy [105]. Autophagy is generally considered as a protective and adaptive stress response, but in some cellular settings, autophagy may also contribute to cell death [106]. Indeed, BETd provoked autophagy-induced apoptosis in senescent cells that was achieved, at least in part, by up-regulation of autophagic gene expression [105].

Several other strategies have been recently proposed to provide more accurate and targeted senolytic-based interventions. These include nanotechnology-based approaches for detection, site-specific delivery of senolytics and/or senoprobes, and successful elimination of SCs [83,107-110]. As cellular senescence may be implicated in the pathogenesis of age-related neurodegenerative diseases such as Alzheimer's disease and Parkinson's disease [111,112], the use of nano-senolytics in the central nervous system (CNS) seems promising. One should remember that nano-based systems are able to overcome the blood-brain barrier and improve the delivery of encapsulated therapeutic agents and dietary polyphenols at lower systemic doses [68,74].

\section{Nanomaterials for the Clearance of Senescent Cells}

As the main purpose of senotherapy is to kill SCs, safe and effective detection and targeting of these cells is crucial to improving human health and prolonging lifespan [113]. Nano-based systems developed to identify and kill senescent cells can be considered as second-generation targeted and selective senolytics that are able to efficiently eliminate senescent cells upon systemic administration without causing adverse side effects. One of the best-explored groups of nano-senolytics is smart nanodevices that are based on porous calcium carbonate nanoparticles, mesoporous silica nanoparticles, carbon quantum dots, and molecularly-imprinted polymer nanoparticles (nanoMIPs) (Figure 4) [114]. Targeted delivery and detection/elimination of SCs can be achieved by encapsulation of senolytics/senomorphics/fluorophores using a number of nanomaterials. For example, cargo release in the presence of $\beta$-galactosidase ( $\beta$-gal) was due to the hydrolysis of the capping galacto-oligosaccharide (Gal) polymer [109]. In vitro studies demonstrated that nanomaterials covered with Gal and loaded with fluorophores (e.g., rhodamine B, indocyanine green, coumarin-6, or Nile blue) were preferentially activated in $\beta$-galactosidase-overexpressing SCs, which were able to lyse the galacto-oligosaccharide coat (Figure 3) [85,114]. Moreover, $\beta$-galactosidase-instructed supramolecular assemblies can also lead to the formulation of hydrogels and nanofibers in SCs, which decreases the expression of senescence-driving proteins [115]. Apart from $\beta$-gal, increased expression of other lysosomal hydrolases (e.g., $\alpha$-L-fucosidase) has been used for detection of senescent cells [116]. To date, a collection of senoprobes has been described [114]. Nano-based senoprobes could be utilized to monitor the response of tumors to the administration of senescence-inducing chemotherapeutic drugs. More recently, another method for the real-time in vivo detection of senescent cells based on mesoporous silica nanoparticles loaded with Nile blue and coated with a galacto-hexasaccharide was proposed [117]. Functionalized nanomaterials appear to have a promising potential as nanocarriers and can be used for improving SC clearance. Table 1 provides published examples of in vitro and in vivo senotherapeutic action of nano-based drug delivery systems [83,107-110,114,118-121]. 


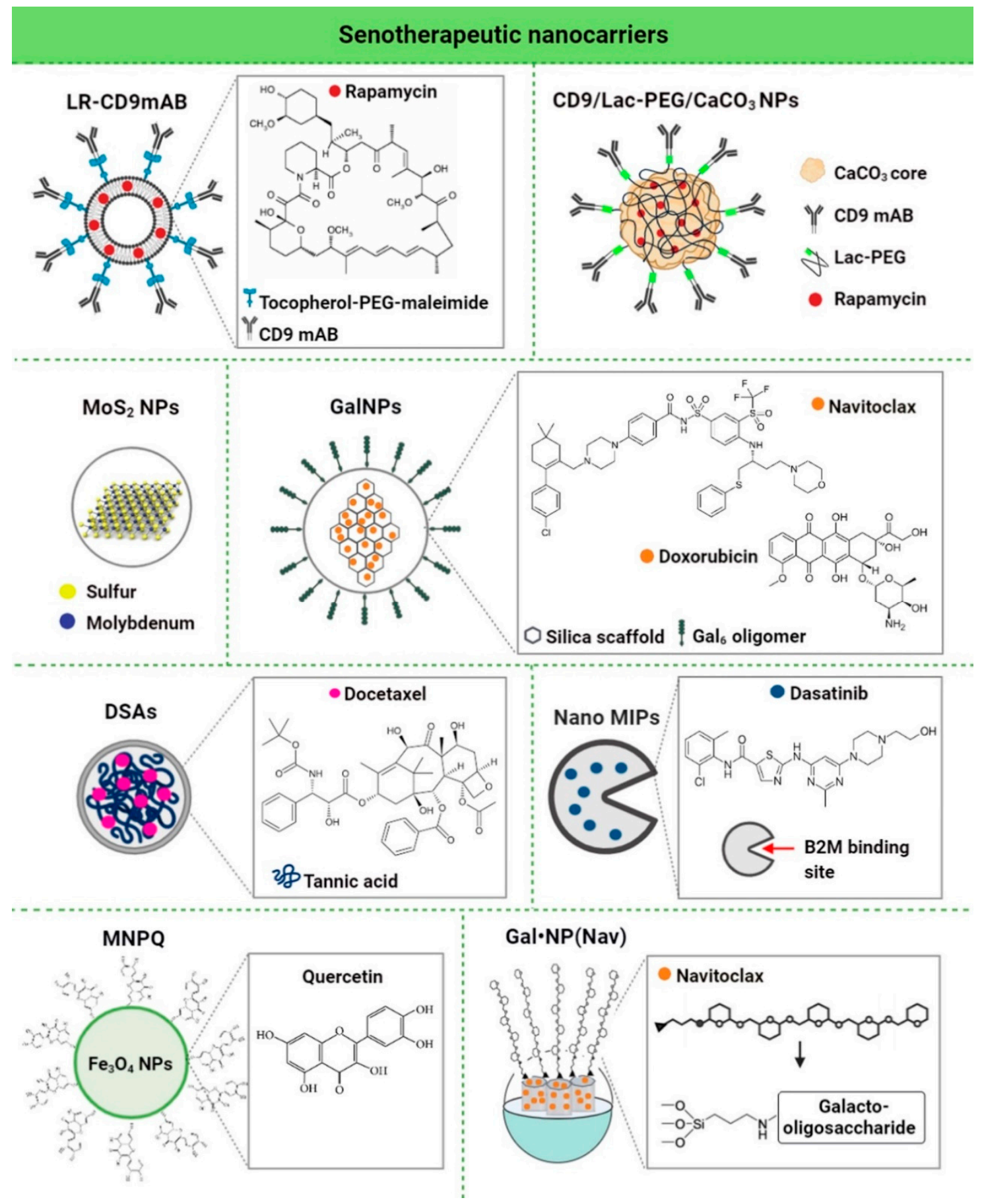

Figure 4. Different examples of nanocarriers used for targeted delivery of senolytics/senomorphics to senescent cells. Chemical structures of the loaded cargos are presented. LR, rapamycin-loaded PEGylated liposomes; NPs, nanoparticles; PEG, polyethylene glycol; Lac-PEG, lactose-polyethylene glycol; Gal, galacto-oligosaccharide; DSAs, docetaxel-tannic acid self-assemblies; NanoMIPs, molecularly imprinted nanoparticles; $\mathrm{B} 2 \mathrm{M}$, beta-2 microglobulin; $\mathrm{Gal}_{6}$, 6-mer galacto-oligosaccharide; $\mathrm{Nav}$, navitoclax; $\mathrm{MNPQ}$, quercetin surface-functionalized $\mathrm{Fe}_{3} \mathrm{O}_{4}$ nanoparticles. 
Table 1. Nanomaterials targeting senescent cells using cellular in vitro and in vivo models.

\begin{tabular}{|c|c|c|c|c|c|c|}
\hline Nanomaterial & $\begin{array}{l}\text { Biologically- } \\
\text { Active Component }\end{array}$ & Concentration & Senescence Model & $\begin{array}{l}\text { In Vitro/In Vivo } \\
\text { Model }\end{array}$ & Senolytic Effects and Mechanism & Ref. \\
\hline $\begin{array}{l}\text { LR-CD9mAb CD9 monoclonal } \\
\text { antibody conjugated to } \\
\text { PEGylated liposomes }\end{array}$ & Rapa & $25 \mathrm{nM}$ & $\begin{array}{c}\text { Human dermal } \\
\text { fibroblasts (HDF), } \\
\text { doxorubicin-induced } \\
\text { senescence }\end{array}$ & In vitro & $\begin{array}{c}\text { Anti-senescence activity (increased } \\
\text { proliferative potential, decreased } \\
\beta \text {-galactosidase activity and p53/p21 } \\
\text { expression, and increased cell migration) }\end{array}$ & [118] \\
\hline $\begin{array}{c}\mathrm{CD} 9-\mathrm{Lac} / \mathrm{CaCO}_{3} / \mathrm{Rapa} \mathrm{NPs} \\
\mathrm{CD} 9 \text { monoclonal } \\
\text { antibody-conjugated } \\
\text { lactose-wrapped calcium } \\
\text { carbonate nanoparticles loaded } \\
\text { with rapamycin } \\
\end{array}$ & Rapa & $\begin{array}{l}0.2 \mathrm{mg} \text { of rapamycin } \\
\text { per mg of } \mathrm{CaCO}_{3} \mathrm{NPs}\end{array}$ & $\begin{array}{l}\text { Human dermal } \\
\text { fibroblasts (HDF), } \\
\text { replicative and } \\
\text { doxorubicin-induced } \\
\text { senescence }\end{array}$ & In vitro & $\begin{array}{c}\text { Anti-senescence activity (decreased } \\
\beta \text {-galactosidase activity and } \\
\text { p53/p21/CD9/cyclin D1 expression, increased } \\
\text { cell proliferation and cell migration ability, } \\
\text { decreased population doubling time, and } \\
\text { prevention of G1 cell cycle arrest) }\end{array}$ & [107] \\
\hline $\begin{array}{l}\mathrm{MoS}_{2} \mathrm{NPs} \text { molybdenum } \\
\text { disulfide mesoporous silica } \\
\text { nanoparticles }\end{array}$ & - & $50 \mu \mathrm{g} / \mathrm{mL}$ & $\begin{array}{c}\text { Human aortic } \\
\text { endothelial cells } \\
\text { (HAECs), } \\
\text { stress-induced } \\
\text { premature senescence }\end{array}$ & In vitro & $\begin{array}{l}\text { Anti-senescence activity (decreased } \gamma-\mathrm{H} 2 \mathrm{AX} \\
\text { phosphorylation, repressed upregulation of } \\
\text { p16, p21 and p53, activation of autophagy, } \\
\text { improved autophagic flux, and prevention of } \\
\text { lysosomal and mitochondrial dysfunction) }\end{array}$ & [108] \\
\hline $\begin{array}{l}\text { GalNP(dox) 6-mer } \\
\text { galacto-oligosaccharide } \\
\text { encapsulated doxorubicin }\end{array}$ & Dox & $1 \mathrm{mg} / \mathrm{kg}$ & $\begin{array}{c}\text { Mouse, } \\
\text { bleomycin-induced } \\
\text { lung fibrosis }\end{array}$ & In vivo & $\begin{array}{l}\text { Anti-senescence activity } \\
\text { (improved lung function) }\end{array}$ & \multirow{4}{*}{ [109] } \\
\hline $\begin{array}{l}\text { GalNP(nav) 6-mer } \\
\text { galacto-oligosaccharide } \\
\text { encapsulated navitoclax }\end{array}$ & $\mathrm{Nav}$ & $0.06 \mathrm{mg} / \mathrm{mL}$ & $\begin{array}{l}\text { Melanoma } \\
\text { (SK-MEL-103), } \\
\text { palbociclib-induced } \\
\text { senescence }\end{array}$ & In vitro & Senolytic activity (apoptosis of senescent cells) & \\
\hline $\begin{array}{c}\text { GalNP(dox) 6-mer } \\
\text { galacto-oligosaccharide } \\
\text { encapsulated doxorubicin }\end{array}$ & Dox & \multirow{2}{*}{$1 \mathrm{mg} / \mathrm{kg}$} & \multirow{2}{*}{$\begin{array}{l}\text { Mouse-bearing } \\
\text { SK-MEL-103 tumor } \\
\text { xenografts, } \\
\text { palbociclib-induced } \\
\text { tumor senescence }\end{array}$} & \multirow[b]{2}{*}{ In vivo } & \multirow{2}{*}{$\begin{array}{l}\text { Clearance of senescent cells and induced } \\
\text { regression of tumor xenografts }\end{array}$} & \\
\hline $\begin{array}{c}\text { GalNP(nav) 6-mer } \\
\text { galacto-oligosaccharide } \\
\text { encapsulated navitoclax }\end{array}$ & $\mathrm{Nav}$ & & & & & \\
\hline \multirow{2}{*}{$\begin{array}{l}\text { DSAs Docetaxel-tannic acid } \\
\text { self-assemblies (DSAs)-based } \\
\text { nanoparticles }\end{array}$} & \multirow{2}{*}{ Docetaxel } & $2.5-5 \mathrm{nM}$ & $\begin{array}{l}\text { Prostate cancer cells } \\
\quad(\text { C4-2 and PC- } 3)\end{array}$ & In vitro & $\begin{array}{l}\text { Senolytic activity (inhibition of } \\
\text { senescence-related TGF } \beta \text { R1, FOXO1, and p21 } \\
\text { proteins and activation of apoptosis) }\end{array}$ & \multirow{2}{*}{ [119] } \\
\hline & & $30 \mathrm{mg} / \mathrm{kg}$ & $\begin{array}{l}\text { Mouse-bearing PC-3 } \\
\text { tumor xenografts }\end{array}$ & In vivo & $\begin{array}{l}\text { Clearance of senescent cells (induced } \\
\text { regression of tumor xenografts by blockade of } \\
\text { TGF } \beta R 1 / \text { p21-mediated senescence signaling } \\
\text { and activation of apoptosis) }\end{array}$ & \\
\hline
\end{tabular}


Table 1. Cont

\begin{tabular}{|c|c|c|c|c|c|c|}
\hline Nanomaterial & $\begin{array}{l}\text { Biologically- } \\
\text { Active Component }\end{array}$ & Concentration & Senescence Model & $\begin{array}{l}\text { In Vitro/In Vivo } \\
\text { Model }\end{array}$ & Senolytic Effects and Mechanism & Ref. \\
\hline $\begin{array}{c}\text { NanoMIPs } \\
\text { molecularly-imprinted } \\
\text { nanoparticles }\end{array}$ & Dasatinib & $\begin{array}{c}10 \mu \mathrm{M} \\
\text { dasatinib-conjugated } \\
\text { B2M nanoMIPs }\end{array}$ & $\begin{array}{l}\text { Bladder cancer cells } \\
\text { with a tetracycline } \\
\text { (tet)-regulatable p16 } \\
\text { expression systems } \\
\text { (EJp16) }\end{array}$ & In vitro & $\begin{array}{l}\text { Senolytic activity (decreased number of } \\
\text { senescent cancer cells) }\end{array}$ & [110] \\
\hline $\begin{array}{c}\text { MNPQ quercetin } \\
\text { surface-functionalized } \mathrm{Fe}_{3} \mathrm{O}_{4} \\
\text { nanoparticles }\end{array}$ & Quercetin & $5 \mu \mathrm{g} / \mathrm{mL}$ & $\begin{array}{l}\text { Human foreskin } \\
\text { fibroblasts (BJ), } \\
\text { hydrogen } \\
\text { peroxide-induced } \\
\text { senescence }\end{array}$ & In vitro & $\begin{array}{l}\text { Senolytic and senostatic activity (AMPK } \\
\text { activation, induction of non-apoptotic cell } \\
\text { death, and inhibition of SASP components, } \\
\text { namely IL- } 6 \text { and IFN- } \beta \text { ) }\end{array}$ & [120] \\
\hline GalNP(nav) & $\mathrm{Nav}$ & $\begin{array}{c}40 \mathrm{mg} \text { GalNP } \\
(\mathrm{Nav}) / \mathrm{kg}(\approx 2.5 \mathrm{mg} / \mathrm{kg} \\
\text { of free navitoclax })\end{array}$ & $\begin{array}{l}\text { Triple-negative breast } \\
\text { cancer mouse model, } \\
\text { palbociclib-induced } \\
\text { senescence }\end{array}$ & In vivo & $\begin{array}{l}\text { Senolytic activity (inhibited tumor growth, } \\
\text { reduced metastasis, and limited systemic } \\
\text { toxicity of navitoclax, and apoptosis of } \\
\text { senescent cancer cells) }\end{array}$ & [121] \\
\hline
\end{tabular}

Abbreviations: Rapa, rapamycin; Dox, doxorubicin; Nav, navitoclax. 
The first-reported SC-targeted cargo delivery nano-system is a nano-structure based on mesoporous silica nanoparticles (MSN S1) coated with galacto-oligosaccharides and loaded with rhodamine B [85]. MSN S1 are engulfed by human SCs and activated by SA- $\beta$-gal. There are also studies showing that encapsulation of a senolytic agent, namely navitoclax with $\beta(1,4)$-galacto-oligosaccharides is effective in clearing SCs in models of damage-induced and chemotherapy-induced senescence [109]. Nanostructures conjugated with drugs may also exert a senomorphic effect by inhibiting the SASP $[107,120]$. A recent in vitro study demonstrated that nanoparticles functionalized with monoclonal antibody against CD9 receptor (overexpressed in old cells) and loaded with rapamycin (an mTOR inhibitor with well-recognized anti-aging activity) (CD9-Lac/ $\mathrm{CaCO}_{3} / \mathrm{Rapa} \mathrm{NPs}$ ) have anti-senescence effect [107]. CD9-Lac/ $\mathrm{CaCO}_{3} /$ Rapa NPs significantly improved the proliferative capacity of SCs, which was accompanied by lower expression of IL- 6 and IL-1 $\beta$, the SASP components [107]. Moreover, CD9-targeted PEGylated liposomes have been documented as a promising drug delivery platform to target senescent cells [118]. The uptake of CD9-targeted liposomes by premature senescent human dermal fibroblasts (HDFs) was revealed to be higher than that by young HDFs [118]. Targeted delivery of rapamycin (LR-CD9mAb) to diminish senescence of CD9-receptor-overexpressing cells was also explored and rapamycin was found to promote cell proliferation and reduce the levels of SA- $\beta$-gal-positive cells [118]. Another study performed by Ke et al. [108] showed that $\mathrm{MoS}_{2} \mathrm{NPs}$ suppressed hydrogen-peroxide-induced senescence in endothelial cells. In addition, $\mathrm{MoS}_{2} \mathrm{NP}$ treatment leads to autophagy activation, which suppressed SIPS in vitro [108]. More recently, the docetaxel-tannic acid self-assembly (DSA)-based nanoparticle strategy has been developed and documented to be an efficient delivery system to provide docetaxel to prostate cancer cells and xenograft tumors and diminish cellular senescence [119]. DSAs-induced anti-senescence and anti-cancer effects were mediated by the inhibition of TGF $\beta$ R1/FOXO1/p21-associated senescence and apoptosis induction in vitro and in vivo [119]. The authors concluded that DSAs can be considered as a useful nano-platform to deliver anticancer molecules (here docetaxel) to cancer cells that would result in improved therapeutic benefits and limited chemotherapy-induced senescence and drug resistance [119]. Targeted clearance of SCs using B2M ( $\beta 2$ microglobulin) nanoMIPs (molecularly imprinted nanoparticles) has been also described [110]. B2M nanoMIPs specifically recognize one of the previously-identified members of a cell membrane surface protein that is overexpressed in SCs, namely B2M [110]. In addition, it has been shown that B2M nanoMIPs loaded with a senolytic drug (dasatinib) can kill senescent bladder cancer cells [110]. Moreover, fluorescently-tagged nanoMIPs detected senescent cells in vivo and were not toxic when injected at single doses [110]. The authors concluded that nanoMIPs may have diagnostic, prognostic, and therapeutic potential when considering the pathological conditions mediated by the accumulation of senescent cells [110]. We have also documented a senolytic and senostatic activity of quercetin surface-functionalized magnetite nanoparticles (MNPQ) in prematurely-senescent human fibroblasts (hydrogen peroxide treatment in vitro) [120]. It has been shown that MNPQ are able to eliminate senescent human fibroblast cells in vitro [120]. MNPQ diminish senescence-mediated proinflammatory response as judged by decreased secretion of IL- 8 and IFN- $\beta$ that was accompanied by the activation of AMP-activated protein kinase (AMPK) [120].

\section{Conclusions}

The nano-based drug delivery system and its applications in the field of aging research have developed and evolved over the last several years. Because of their nano-sized nature and their ability to meet diverse functionalities, senescent-cell-targeted nanocarriers may have potential for elimination of senescent cells from the human body, which may improve the treatment of age-related disorders. However, many challenges restrain their successful clinical translation. Firstly, our current knowledge about molecular mechanisms underlying cellular senescence and modulating senescence-associated secretory phenotype in the context of age-associated disorders is not yet complete. In addition, successful application of senotherapeutic nanocarriers may depend on the development of best-suited methods for minimizing potential off-target effects and maximizing on-target effects. Next, for those 
who study senescent-cell-targeted nanocarriers, it may be challenging to find an optimal nanocarrier type for senolytic drug delivery as well as optimal biocompatible concentration(s), improved drug encapsulation, and ligand conjugation efficiency. The parameters of nanocarrier absorption, interactions with human biological fluids, distribution, metabolism, and excretion are also important for future anti-aging applications of senotherapeutic nanocarriers. In conclusion, a nano-based drug delivery system constitutes a novel strategy to target senescent cells for potential therapeutic interventions. While few initial studies are promising, additional further studies involving the development of second-generation targeted and selective senolytics, namely senescence-targeted nanocarriers and validation of nano-senolytics using preclinical aging model systems and clinical trials are needed to determine whether these nanodevices might be effective against age-related diseases.

Author Contributions: Conceptualization, J.A.-G. and A.L.; writing-original draft preparation, J.A.-G. and A.L.; writing-review and editing, J.A.-G. and A.L.; visualization, J.A.-G.; supervision, J.A.-G. and A.L. All authors have read and agreed to the published version of the manuscript.

Funding: This research received no external funding.

Acknowledgments: Figures were created using Biorender, https://biorender.com/.

Conflicts of Interest: The authors declare no conflict of interest.

\section{Abbreviations}

\begin{tabular}{|c|c|}
\hline 17-AAG & tanespimycin \\
\hline 17-DMAG & alvespimycin \\
\hline AKT & protein kinase $B$ \\
\hline AMPK & AMP-activated protein kinase \\
\hline B2M & Beta-2 microglobulin \\
\hline Bcl-2 & B cell lymphoma 2 family \\
\hline BETd & BET family protein degrader \\
\hline CAR & Chimeric antigen receptor \\
\hline CCL-16 & Monotactin-1 \\
\hline CDKI & Cyclin-dependent kinase inhibitor \\
\hline CS & Cellular senescence \\
\hline DAMPs & Damage-associated molecular patterns \\
\hline DDR & DNA damage response \\
\hline DNA & Deoxyribonucleic acid \\
\hline Dox & Doxorubicin \\
\hline DSAs & Docetaxel-tannic acid self-assemblies \\
\hline EGF & Endothelial growth factor \\
\hline EGF & Epidermal growth factor \\
\hline EVs & Extracellular vesicles \\
\hline FOXO4 & Forkhead box protein $\mathrm{O} 4$ \\
\hline Gal & Galacto-oligosaccharide \\
\hline $\mathrm{Gal}_{6}$ & 6-mer galacto-oligosaccharide \\
\hline HAECs & Human aortic endothelial cells \\
\hline HDF & Human dermal fibroblasts \\
\hline HIF- $1 \alpha$ & Hypoxia inducible factor $1 \alpha$ \\
\hline HSP90 & Chaperone heat shock protein 90 \\
\hline IFN- $\beta$ & Interferon beta \\
\hline IGF-1 & Insulin-like growth factor 1 \\
\hline IL-6 & Interleukin 6 \\
\hline IL-8 & Interleukin 8 \\
\hline IL-1 $\beta$ & Interleukin $1 \beta$ \\
\hline JAK & Janus kinase \\
\hline Lac-PEG & Lactose-polyethylene glycol \\
\hline LR & Rapamycin-loaded PEGylated liposomes \\
\hline
\end{tabular}




$\begin{array}{ll}\text { MAPK } & \text { Mitogen-activated protein kinase } \\ \text { MCP-1 } & \text { Monocyte chemoattractant protein } 1 \\ \text { MIP-1 } \alpha & \text { Macrophage inflammatory protein } 1 \alpha \\ \text { miRNA } & \text { MicroRNA } \\ \text { MMPs } & \text { Metalloproteinases } \\ \text { MoS } 2 & \text { Molybdenum disulfide } \\ \text { MNPQ } & \text { Quercetin surface-functionalized } \mathrm{Fe}_{3} \mathrm{O}_{4} \text { nanoparticles } \\ \text { MSN } & \text { Mesoporous silica nanoparticles } \\ \text { mTOR } & \text { Mammalian target of rapamycin } \\ \text { nanoMIPs } & \text { Molecularly-imprinted polymer nanoparticles } \\ \text { Nav } & \text { Navitoclax } \\ \text { NF } & \text { Nuclear factor } \\ \text { NHEJ } & \text { Non-homologous end joining } \\ \text { NPs } & \text { Nanoparticles } \\ \text { OIS } & \text { Oncogene-induced senescence } \\ \text { p16 } & \text { Cyclin-dependent kinase inhibitor 2A } \\ \text { p21 } & \text { Cyclin-dependent kinase inhibitor 1A } \\ \text { p53 } & \text { Tumor suppressor protein p53 } \\ \text { PEG } & \text { Polyethylene glycol } \\ \text { PI3K } & \text { Phosphatidylinositol-3-kinase } \\ \text { Rapa } & \text { Rapamycin } \\ \text { Rb } & \text { Retinoblastoma } \\ \text { RNA } & \text { Ribonucleic acid } \\ \text { ROS } & \text { Reactive oxygen species } \\ \text { SAHF } & \text { Senescence-associated heterochromatin foci } \\ \text { SASP } & \text { Senescence-associated secretory phenotype } \\ \text { SA- } \beta \text {-gal } & \text { Senescence associated } \beta \text {-galactosidase } \\ \text { SCAPs } & \text { Senescent cell anti-apoptotic pathways } \\ \text { SCs } & \text { Senescent cells } \\ \text { SIPS } & \text { Stress-induced premature senescence } \\ \text { siRNA } & \text { Small interfering RNA } \\ \text { STAT } & \text { Signal transducer and activator of transcription } \\ \text { uPAR } & \text { Urokinase-type plasminogen activator receptor } \\ & \end{array}$

\section{References}

1. Rodier, F.; Campisi, J. Four faces of cellular senescence. J. Cell Biol. 2011, 192, 547-556. [CrossRef] [PubMed]

2. Herranz, N.; Gil, J. Mechanisms and functions of cellular senescence. J. Clin. Investig. 2018, 128, $1238-1246$. [CrossRef] [PubMed]

3. Hayflick, L.; Moorhead, P.S. The serial cultivation of human diploid cell strains. Exp. Cell Res. 1961, 25, 585-621. [CrossRef]

4. Shay, J.W.; Wright, W.E. Telomeres and telomerase: Three decades of progress. Nat. Rev. Genet. 2019, 20, 299-309. [CrossRef]

5. Bodnar, A.G. Extension of Life-Span by Introduction of Telomerase into Normal Human Cells. Science 1998, 279, 349-352. [CrossRef]

6. Dimri, G.P.; Lee, X.; Basile, G.; Acosta, M.; Scott, G.; Roskelley, C.; Medrano, E.E.; Linskens, M.; Rubelj, I.; Pereira-Smith, O. A biomarker that identifies senescent human cells in culture and in aging skin in vivo. Proc. Natl. Acad. Sci. USA 1995, 92, 9363-9367. [CrossRef]

7. Chen, Q.; Fischer, A.; Reagan, J.D.; Yan, L.J.; Ames, B.N. Oxidative DNA damage and senescence of human diploid fibroblast cells. Proc. Natl. Acad. Sci. USA 1995, 92, 4337-4341. [CrossRef]

8. Kuilman, T.; Michaloglou, C.; Mooi, W.J.; Peeper, D.S. The essence of senescence. Genes Dev. 2010, 24, 2463-2479. [CrossRef] 
9. Toussaint, O.; Medrano, E.E.; von Zglinicki, T. Cellular and molecular mechanisms of stress-induced premature senescence (SIPS) of human diploid fibroblasts and melanocytes. Exp. Gerontol. 2000, 35, 927-945. [CrossRef]

10. Serrano, M.; Lin, A.W.; McCurrach, M.E.; Beach, D.; Lowe, S.W. Oncogenic ras Provokes Premature Cell Senescence Associated with Accumulation of p53 and p16INK4a. Cell 1997, 88, 593-602. [CrossRef]

11. Collado, M.; Serrano, M. Senescence in tumours: Evidence from mice and humans. Nat. Rev. Cancer 2010, 10, 51-57. [CrossRef] [PubMed]

12. Storer, M.; Mas, A.; Robert-Moreno, A.; Pecoraro, M.; Ortells, M.C.; Di Giacomo, V.; Yosef, R.; Pilpel, N.; Krizhanovsky, V.; Sharpe, J.; et al. Senescence Is a Developmental Mechanism that Contributes to Embryonic Growth and Patterning. Cell 2013, 155, 1119-1130. [CrossRef] [PubMed]

13. Muñoz-Espín, D.; Serrano, M. Cellular senescence: From physiology to pathology. Nat. Rev. Mol. Cell Biol. 2014, 15, 482-496. [CrossRef] [PubMed]

14. Tchkonia, T.; Morbeck, D.E.; Von Zglinicki, T.; Van Deursen, J.; Lustgarten, J.; Scrable, H.; Khosla, S.; Jensen, M.D.; Kirkland, J.L. Fat tissue, aging, and cellular senescence: Fat tissue and aging. Aging Cell 2010, 9, 667-684. [CrossRef] [PubMed]

15. Naylor, R.M.; Baker, D.J.; van Deursen, J.M. Senescent cells: A novel therapeutic target for aging and age-related diseases. Clin. Pharmacol. Ther. 2013, 93, 105-116. [CrossRef] [PubMed]

16. van Deursen, J.M. The role of senescent cells in ageing. Nature 2014, 509, 439-446. [CrossRef] [PubMed]

17. He, S.; Sharpless, N.E. Senescence in Health and Disease. Cell 2017, 169, 1000-1011. [CrossRef] [PubMed]

18. Kritsilis, M.; Rizou, V.S.; Koutsoudaki, P.N.; Evangelou, K.; Gorgoulis, V.G.; Papadopoulos, D. Ageing, Cellular Senescence and Neurodegenerative Disease. Int. J. Mol. Sci. 2018, 19, 2937. [CrossRef] [PubMed]

19. Palmer, A.K.; Gustafson, B.; Kirkland, J.L.; Smith, U. Cellular senescence: At the nexus between ageing and diabetes. Diabetologia 2019, 62, 1835-1841. [CrossRef] [PubMed]

20. Wei, W.; Ji, S. Cellular senescence: Molecular mechanisms and pathogenicity. J. Cell. Physiol. 2018, 233, 9121-9135. [CrossRef] [PubMed]

21. Sikora, E.; Bielak-Zmijewska, A.; Mosieniak, G. Targeting normal and cancer senescent cells as a strategy of senotherapy. Ageing Res. Rev. 2019, 55, 100941. [CrossRef] [PubMed]

22. Terzi, M.Y.; Izmirli, M.; Gogebakan, B. The cell fate: Senescence or quiescence. Mol. Biol. Rep. 2016, 43, 1213-1220. [CrossRef] [PubMed]

23. Sharpless, N.E.; Sherr, C.J. Forging a signature of in vivo senescence. Nat. Rev. Cancer 2015, 15, $397-408$. [CrossRef] [PubMed]

24. Childs, B.G.; Gluscevic, M.; Baker, D.J.; Laberge, R.M.; Marquess, D.; Dananberg, J.; van Deursen, J.M. Senescent cells: An emerging target for diseases of ageing. Nat Rev Drug Discov. 2017, 16, 718-735. [CrossRef] [PubMed]

25. von Kobbe, C. Targeting senescent cells: Approaches, opportunities, challenges. Aging 2019, 11, 12844-12861. [CrossRef] [PubMed]

26. Coppé, J.-P.; Patil, C.K.; Rodier, F.; Sun, Y.; Muñoz, D.P.; Goldstein, J.; Nelson, P.S.; Desprez, P.-Y.; Campisi, J. Senescence-associated secretory phenotypes reveal cell-nonautonomous functions of oncogenic RAS and the p53 tumor suppressor. PLoS Biol. 2008, 6, 2853-2868. [CrossRef]

27. Kuilman, T.; Peeper, D.S. Senescence-messaging secretome: SMS-ing cellular stress. Nat. Rev. Cancer 2009, 9, 81-94. [CrossRef]

28. Rodier, F.; Coppé, J.-P.; Patil, C.K.; Hoeijmakers, W.A.M.; Muñoz, D.P.; Raza, S.R.; Freund, A.; Campeau, E.; Davalos, A.R.; Campisi, J. Persistent DNA damage signalling triggers senescence-associated inflammatory cytokine secretion. Nat. Cell Biol. 2009, 11, 973-979. [CrossRef]

29. Coppé, J.-P.; Desprez, P.-Y.; Krtolica, A.; Campisi, J. The senescence-associated secretory phenotype: The dark side of tumor suppression. Annu. Rev. Pathol. 2010, 5, 99-118. [CrossRef]

30. Kirkland, J.L.; Tchkonia, T. Cellular Senescence: A Translational Perspective. EBioMedicine 2017, 21, 21-28. [CrossRef]

31. Panda, A.C.; Abdelmohsen, K.; Gorospe, M. SASP regulation by noncoding RNA. Mech. Ageing Dev. 2017, 168, 37-43. [CrossRef] [PubMed]

32. Kang, T.-W.; Yevsa, T.; Woller, N.; Hoenicke, L.; Wuestefeld, T.; Dauch, D.; Hohmeyer, A.; Gereke, M.; Rudalska, R.; Potapova, A.; et al. Senescence surveillance of pre-malignant hepatocytes limits liver cancer development. Nature 2011, 479, 547-551. [CrossRef] [PubMed] 
33. Yun, M.H. Cellular senescence in tissue repair: Every cloud has a silver lining. Int. J. Dev. Biol. 2018, 62, 591-604. [CrossRef] [PubMed]

34. Acosta, J.C.; O’Loghlen, A.; Banito, A.; Guijarro, M.V.; Augert, A.; Raguz, S.; Fumagalli, M.; Da Costa, M.; Brown, C.; Popov, N.; et al. Chemokine Signaling via the CXCR2 Receptor Reinforces Senescence. Cell 2008, 133, 1006-1018. [CrossRef]

35. Krtolica, A.; Parrinello, S.; Lockett, S.; Desprez, P.-Y.; Campisi, J. Senescent fibroblasts promote epithelial cell growth and tumorigenesis: A link between cancer and aging. Proc. Natl. Acad. Sci. USA 2001, 98, 12072. [CrossRef]

36. Vizioli, M.G.; Adams, P.D. Senescence Can Be BETter without the SASP? Cancer Discov. 2016, 6, 576-578. [CrossRef]

37. Soto-Gamez, A.; Demaria, M. Therapeutic interventions for aging: The case of cellular senescence. Drug Discov. Today 2017, 22, 786-795. [CrossRef]

38. Sakoda, K.; Yamamoto, M.; Negishi, Y.; Liao, J.K.; Node, K.; Izumi, Y. Simvastatin Decreases IL-6 and IL-8 Production in Epithelial Cells. J. Dent. Res. 2006, 85, 520-523. [CrossRef]

39. Lim, H.; Park, H.; Kim, H.P. Effects of flavonoids on senescence-associated secretory phenotype formation from bleomycin-induced senescence in BJ fibroblasts. Biochem. Pharmacol. 2015, 96, 337-348. [CrossRef]

40. Hoare, M.; Ito, Y.; Kang, T.-W.; Weekes, M.P.; Matheson, N.J.; Patten, D.A.; Shetty, S.; Parry, A.J.; Menon, S.; Salama, R.; et al. NOTCH1 mediates a switch between two distinct secretomes during senescence. Nat. Cell Biol. 2016, 18, 979-992. [CrossRef]

41. Nelson, G.; Wordsworth, J.; Wang, C.; Jurk, D.; Lawless, C.; Martin-Ruiz, C.; von Zglinicki, T. A senescent cell bystander effect: Senescence-induced senescence. Aging Cell 2012, 11, 345-349. [CrossRef] [PubMed]

42. Lehmann, B.D.; Paine, M.S.; Brooks, A.M.; McCubrey, J.A.; Renegar, R.H.; Wang, R.; Terrian, D.M. Senescence-Associated Exosome Release from Human Prostate Cancer Cells. Cancer Res. 2008, 68, 7864-7871. [CrossRef] [PubMed]

43. Fuhrmann-Stroissnigg, H.; Niedernhofer, L.J.; Robbins, P.D. Hsp90 inhibitors as senolytic drugs to extend healthy aging. Cell Cycle Georget. Tex 2018, 17, 1048-1055. [CrossRef] [PubMed]

44. Sajja, H.; East, M.; Mao, H.; Wang, Y.; Nie, S.; Yang, L. Development of Multifunctional Nanoparticles for Targeted Drug Delivery and Noninvasive Imaging of Therapeutic Effect. Curr. Drug Discov. Technol. 2009, 6, 43-51. [CrossRef]

45. Obeid, M.A.; Al Qaraghuli, M.M.; Alsaadi, M.; Alzahrani, A.R.; Niwasabutra, K.; Ferro, V.A. Delivering natural products and biotherapeutics to improve drug efficacy. Ther. Deliv. 2017, 8, 947-956. [CrossRef]

46. Patra, J.K.; Das, G.; Fraceto, L.F.; Campos, E.V.R.; Rodriguez-Torres, M.P.; Acosta-Torres, L.S.; Diaz-Torres, L.A.; Grillo, R.; Swamy, M.K.; Sharma, S.; et al. Nano based drug delivery systems: Recent developments and future prospects. J. Nanobiotechnol. 2018, 16, 71. [CrossRef]

47. Chenthamara, D.; Subramaniam, S.; Ramakrishnan, S.G.; Krishnaswamy, S.; Essa, M.M.; Lin, F.-H.; Qoronfleh, M.W. Therapeutic efficacy of nanoparticles and routes of administration. Biomater. Res. 2019, 23, 20. [CrossRef]

48. Farokhzad, O.; Langer, R. Nanomedicine: Developing smarter therapeutic and diagnostic modalities. Adv. Drug Deliv. Rev. 2006, 58, 1456-1459. [CrossRef]

49. Nie, S.; Xing, Y.; Kim, G.J.; Simons, J.W. Nanotechnology Applications in Cancer. Annu. Rev. Biomed. Eng. 2007, 9, 257-288. [CrossRef]

50. Seigneuric, R.; Markey, L.; Nuyten, S.A.D.; Dubernet, C.; Evelo, T.A.C.; Finot, E.; Garrido, C. From Nanotechnology to Nanomedicine: Applications to Cancer Research. Curr. Mol. Med. 2010, 10, 640-652. [CrossRef]

51. Kolahalam, L.A.; Kasi Viswanath, I.V.; Diwakar, B.S.; Govindh, B.; Reddy, V.; Murthy, Y.L.N. Review on nanomaterials: Synthesis and applications. Mater. Today Proc. 2019, 18, 2182-2190. [CrossRef]

52. Ventola, C.L. The nanomedicine revolution: Part 1: Emerging concepts. P T Peer-Rev. J. Formul. Manag. 2012, 37, 512-525.

53. Salatin, S.; Yari Khosroushahi, A. Overviews on the cellular uptake mechanism of polysaccharide colloidal nanoparticles. J. Cell. Mol. Med. 2017, 21, 1668-1686. [CrossRef] [PubMed]

54. Kargozar, S.; Mozafari, M. Nanotechnology and Nanomedicine: Start small, think big. Mater. Today Proc. 2018, 5, 15492-15500. [CrossRef] 
55. Paez-Ribes, M.; González-Gualda, E.; Doherty, G.J.; Muñoz-Espín, D. Targeting senescent cells in translational medicine. EMBO Mol. Med. 2019, 11. [CrossRef]

56. Pelaz, B.; del Pino, P.; Maffre, P.; Hartmann, R.; Gallego, M.; Rivera-Fernández, S.; de la Fuente, J.M.; Nienhaus, G.U.; Parak, W.J. Surface Functionalization of Nanoparticles with Polyethylene Glycol: Effects on Protein Adsorption and Cellular Uptake. ACS Nano 2015, 9, 6996-7008. [CrossRef]

57. Schöttler, S.; Becker, G.; Winzen, S.; Steinbach, T.; Mohr, K.; Landfester, K.; Mailänder, V.; Wurm, F.R. Protein adsorption is required for stealth effect of poly(ethylene glycol)- and poly(phosphoester)-coated nanocarriers. Nat. Nanotechnol. 2016, 11, 372-377. [CrossRef]

58. Kolhar, P.; Anselmo, A.C.; Gupta, V.; Pant, K.; Prabhakarpandian, B.; Ruoslahti, E.; Mitragotri, S. Using shape effects to target antibody-coated nanoparticles to lung and brain endothelium. Proc. Natl. Acad. Sci. USA 2013, 110, 10753-10758. [CrossRef]

59. Gao, H.; Yang, Z.; Zhang, S.; Cao, S.; Shen, S.; Pang, Z.; Jiang, X. Ligand modified nanoparticles increases cell uptake, alters endocytosis and elevates glioma distribution and internalization. Sci. Rep. 2013, 3, 2534. [CrossRef]

60. Gao, W.; Zhang, L. Coating nanoparticles with cell membranes for targeted drug delivery. J. Drug Target. 2015, 23, 619-626. [CrossRef]

61. Suk, J.S.; Xu, Q.; Kim, N.; Hanes, J.; Ensign, L.M. PEGylation as a strategy for improving nanoparticle-based drug and gene delivery. Adv. Drug Deliv. Rev. 2016, 99, 28-51. [CrossRef] [PubMed]

62. Zavaleta, C.; Ho, D.; Chung, E.J. Theranostic Nanoparticles for Tracking and Monitoring Disease State. SLAS Technol. Transl. Life Sci. Innov. 2018, 23, 281-293. [CrossRef] [PubMed]

63. Ramanathan, S.; Archunan, G.; Sivakumar, M.; Tamil Selvan, S.; Fred, A.L.; Kumar, S.; Gulyás, B.; Padmanabhan, P. Theranostic applications of nanoparticles in neurodegenerative disorders. Int. J. Nanomed. 2018, 13, 5561-5576. [CrossRef] [PubMed]

64. Haley, B.; Frenkel, E. Nanoparticles for drug delivery in cancer treatment. Urol. Oncol. Semin. Orig. Investig. 2008, 26, 57-64. [CrossRef] [PubMed]

65. Chen, F.; Ehlerding, E.B.; Cai, W. Theranostic nanoparticles. J. Nucl. Med. 2014, 55, 1919-1922. [CrossRef] [PubMed]

66. Chen, G.; Roy, I.; Yang, C.; Prasad, P.N. Nanochemistry and Nanomedicine for Nanoparticle-based Diagnostics and Therapy. Chem. Rev. 2016, 116, 2826-2885. [CrossRef] [PubMed]

67. Riccardi, C.; Fàbrega, C.; Grijalvo, S.; Vitiello, G.; D’Errico, G.; Eritja, R.; Montesarchio, D. AS1411-decorated niosomes as effective nanocarriers for Ru(iii)-based drugs in anticancer strategies. J. Mater. Chem. B 2018, 6, 5368-5384. [CrossRef] [PubMed]

68. Squillaro, T.; Cimini, A.; Peluso, G.; Giordano, A.; Melone, M.A.B. Nano-delivery systems for encapsulation of dietary polyphenols: An experimental approach for neurodegenerative diseases and brain tumors. Biochem. Pharmacol. 2018, 154, 303-317. [CrossRef]

69. Di Martino, P.; Censi, R.; Gigliobianco, M.R.; Zerrillo, L.; Magnoni, F.; Agas, D.; Quaglia, W.; Lupidi, G. Nano-medicine Improving the Bioavailability of Small Molecules for the Prevention of Neurodegenerative Diseases. Curr. Pharm. Des. 2017, 23, 1897-1908. [CrossRef]

70. McClements, D.J.; Xiao, H. Designing food structure and composition to enhance nutraceutical bioactivity to support cancer inhibition. Semin. Cancer Biol. 2017, 46, 215-226. [CrossRef]

71. Squillaro, T.; Peluso, G.; Melone, M.A.B. Nanotechnology-Based Polyphenol Delivery: A Novel Therapeutic Strategy for the Treatment of Age-Related Neurodegenerative Disorder. Austin Aging Res. 2017, 1, 1004.

72. Li, C.; Zhang, J.; Zu, Y.J.; Nie, S.F.; Cao, J.; Wang, Q.; Nie, S.P.; Deng, Z.Y.; Xie, M.Y.; Wang, S. Biocompatible and biodegradable nanoparticles for enhancement of anti-cancer activities of phytochemicals. Chin. J. Nat. Med. 2015, 13, 641-652. [CrossRef]

73. Thomas, O.S.; Weber, W. Overcoming Physiological Barriers to Nanoparticle Delivery-Are We There Yet? Front. Bioeng. Biotechnol. 2019, 7, 415. [CrossRef] [PubMed]

74. Clark, A.J.; Davis, M.E. Increased brain uptake of targeted nanoparticles by adding an acid-cleavable linkage between transferrin and the nanoparticle core. Proc. Natl. Acad. Sci. USA 2015, 112, 12486-12491. [CrossRef] [PubMed]

75. Wang, W.; Sun, C.; Mao, L.; Ma, P.; Liu, F.; Yang, J.; Gao, Y. The biological activities, chemical stability, metabolism and delivery systems of quercetin: A review. Trends Food Sci. Technol. 2016, 56, 21-38. [CrossRef] 
76. Abdelwahab, S.I.; Sheikh, B.Y.; Taha, M.M.E.; How, C.W.; Abdullah, R.; Yagoub, U.; El-Sunousi, R.; Eid, E.E.M. Thymoquinone-loaded nanostructured lipid carriers: Preparation, gastroprotection, in vitro toxicity, and pharmacokinetic properties after extravascular administration. Int. J. Nanomed. 2013, 8, 2163-2172. [CrossRef]

77. Sharma, M.; Sharma, R.; Jain, D.K. Nanotechnology Based Approaches for Enhancing Oral Bioavailability of Poorly Water Soluble Antihypertensive Drugs. Scientifica 2016, 2016, 8525679. [CrossRef]

78. Caster, J.M.; Patel, A.N.; Zhang, T.; Wang, A. Investigational nanomedicines in 2016: A review of nanotherapeutics currently undergoing clinical trials: Investigational nanomedicines in 2016. Wiley Interdiscip. Rev. Nanomed. Nanobiotechnol. 2017, 9, e1416. [CrossRef]

79. Mura, S.; Nicolas, J.; Couvreur, P. Stimuli-responsive nanocarriers for drug delivery. Nat. Mater. 2013, 12, 991-1003. [CrossRef]

80. Liu, J.; Huang, Y.; Kumar, A.; Tan, A.; Jin, S.; Mozhi, A.; Liang, X.-J. pH-Sensitive nano-systems for drug delivery in cancer therapy. Biotechnol. Adv. 2014, 32, 693-710. [CrossRef]

81. Wang, X.; Teng, Z.; Wang, H.; Wang, C.; Liu, Y.; Tang, Y.; Wu, J.; Sun, J.; Wang, H.; Wang, J.; et al. Increasing the cytotoxicity of doxorubicin in breast cancer MCF-7 cells with multidrug resistance using a mesoporous silica nanoparticle drug delivery system. Int. J. Clin. Exp. Pathol. 2014, 7, 1337-1347. [PubMed]

82. Hamidu, A.; Mokrish, A.; Mansor, R.; Razak, I.S.A.; Danmaigoro, A.; Jaji, A.Z.; Bakar, Z.A. Modified methods of nanoparticles synthesis in $\mathrm{pH}$-sensitive nano-carriers production for doxorubicin delivery on MCF-7 breast cancer cell line. Int. J. Nanomed. 2019, 14, 3615-3627. [CrossRef]

83. Muñoz-Espín, D. Nanocarriers targeting senescent cells. Transl. Med. Aging 2019, 3, 1-5. [CrossRef]

84. Lee, B.Y.; Han, J.A.; Im, J.S.; Morrone, A.; Johung, K.; Goodwin, E.C.; Kleijer, W.J.; DiMaio, D.; Hwang, E.S. Senescence-associated $\beta$-galactosidase is lysosomal $\beta$-galactosidase. Aging Cell 2006, 5, 187-195. [CrossRef]

85. Agostini, A.; Mondragón, L.; Bernardos, A.; Martínez-Máñez, R.; Marcos, M.D.; Sancenón, F.; Soto, J.; Costero, A.; Manguan-García, C.; Perona, R.; et al. Targeted Cargo Delivery in Senescent Cells Using Capped Mesoporous Silica Nanoparticles. Angew. Chem. Int. Ed. 2012, 51, 10556-10560. [CrossRef]

86. Ovadya, Y.; Krizhanovsky, V. Strategies targeting cellular senescence. J. Clin. Investig. 2018, 128, $1247-1254$. [CrossRef]

87. Baker, D.J.; Childs, B.G.; Durik, M.; Wijers, M.E.; Sieben, C.J.; Zhong, J.; Saltness, R.A.; Jeganathan, K.B.; Verzosa, G.C.; Pezeshki, A.; et al. Naturally occurring p16(Ink4a)-positive cells shorten healthy lifespan. Nature 2016, 530, 184-189. [CrossRef]

88. Baker, D.J.; Wijshake, T.; Tchkonia, T.; LeBrasseur, N.K.; Childs, B.G.; van de Sluis, B.; Kirkland, J.L.; van Deursen, J.M. Clearance of p16Ink4a-positive senescent cells delays ageing-associated disorders. Nature 2011, 479, 232-236. [CrossRef]

89. Kirkland, J.L.; Tchkonia, T. Clinical strategies and animal models for developing senolytic agents. Exp. Gerontol. 2015, 68, 19-25. [CrossRef]

90. Zhu, Y.; Tchkonia, T.; Pirtskhalava, T.; Gower, A.C.; Ding, H.; Giorgadze, N.; Palmer, A.K.; Ikeno, Y.; Hubbard, G.B.; Lenburg, M.; et al. The Achilles' heel of senescent cells: From transcriptome to senolytic drugs. Aging Cell 2015, 14, 644-658. [CrossRef]

91. Zhu, Y.; Tchkonia, T.; Fuhrmann-Stroissnigg, H.; Dai, H.M.; Ling, Y.Y.; Stout, M.B.; Pirtskhalava, T.; Giorgadze, N.; Johnson, K.O.; Giles, C.B.; et al. Identification of a novel senolytic agent, navitoclax, targeting the Bcl-2 family of anti-apoptotic factors. Aging Cell 2016, 15, 428-435. [CrossRef] [PubMed]

92. González-Gualda, E.; Pàez-Ribes, M.; Lozano-Torres, B.; Macias, D.; Wilson, J.R.; González-López, C.; Ou, H.-L.; Mirón-Barroso, S.; Zhang, Z.; Lérida-Viso, A.; et al. Galacto-conjugation of Navitoclax as an efficient strategy to increase senolytic specificity and reduce platelet toxicity. Aging Cell 2020, e13142. [CrossRef] [PubMed]

93. Justice, J.N.; Nambiar, A.M.; Tchkonia, T.; LeBrasseur, N.K.; Pascual, R.; Hashmi, S.K.; Prata, L.; Masternak, M.M.; Kritchevsky, S.B.; Musi, N.; et al. Senolytics in idiopathic pulmonary fibrosis: Results from a first-in-human, open-label, pilot study. EBioMedicine 2019, 40, 554-563. [CrossRef] [PubMed]

94. Schafer, M.J.; White, T.A.; Iijima, K.; Haak, A.J.; Ligresti, G.; Atkinson, E.J.; Oberg, A.L.; Birch, J.; Salmonowicz, H.; Zhu, Y.; et al. Cellular senescence mediates fibrotic pulmonary disease. Nat. Commun. 2017, 8, 14532. [CrossRef] [PubMed]

95. Ogrodnik, M.; Miwa, S.; Tchkonia, T.; Tiniakos, D.; Wilson, C.L.; Lahat, A.; Day, C.P.; Burt, A.; Palmer, A.; Anstee, Q.M.; et al. Cellular senescence drives age-dependent hepatic steatosis. Nat. Commun. 2017, 8, 15691. [CrossRef] [PubMed] 
96. Farr, J.N.; Xu, M.; Weivoda, M.M.; Monroe, D.G.; Fraser, D.G.; Onken, J.L.; Negley, B.A.; Sfeir, J.G.; Ogrodnik, M.B.; Hachfeld, C.M.; et al. Targeting cellular senescence prevents age-related bone loss in mice. Nat. Med. 2017, 23, 1072-1079. [CrossRef] [PubMed]

97. Zhu, Y.; Doornebal, E.J.; Pirtskhalava, T.; Giorgadze, N.; Wentworth, M.; Fuhrmann-Stroissnigg, H.; Niedernhofer, L.J.; Robbins, P.D.; Tchkonia, T.; Kirkland, J.L. New agents that target senescent cells: The flavone, fisetin, and the BCL- $X_{\mathrm{L}}$ inhibitors, A1331852 and A1155463. Aging 2017, 9, 955-963. [CrossRef]

98. Yousefzadeh, M.J.; Zhu, Y.; McGowan, S.J.; Angelini, L.; Fuhrmann-Stroissnigg, H.; Xu, M.; Ling, Y.Y.; Melos, K.I.; Pirtskhalava, T.; Inman, C.L.; et al. Fisetin is a senotherapeutic that extends health and lifespan. EBioMedicine 2018, 36, 18-28. [CrossRef]

99. Wang, Y.; Chang, J.; Liu, X.; Zhang, X.; Zhang, S.; Zhang, X.; Zhou, D.; Zheng, G. Discovery of piperlongumine as a potential novel lead for the development of senolytic agents. Aging 2016, 8, 2915-2926. [CrossRef]

100. Li, W.; He, Y.; Zhang, R.; Zheng, G.; Zhou, D. The curcumin analog EF24 is a novel senolytic agent. Aging 2019, 11, 771-782. [CrossRef]

101. Samaraweera, L.; Adomako, A.; Rodriguez-Gabin, A.; McDaid, H.M. A Novel Indication for Panobinostat as a Senolytic Drug in NSCLC and HNSCC. Sci. Rep. 2017, 7, 1900. [CrossRef] [PubMed]

102. Baar, M.P.; Brandt, R.M.C.; Putavet, D.A.; Klein, J.D.D.; Derks, K.W.J.; Bourgeois, B.R.M.; Stryeck, S.; Rijksen, Y.; van Willigenburg, H.; Feijtel, D.A.; et al. Targeted Apoptosis of Senescent Cells Restores Tissue Homeostasis in Response to Chemotoxicity and Aging. Cell 2017, 169, 132-147.e16. [CrossRef] [PubMed]

103. Kirkland, J.L.; Tchkonia, T.; Zhu, Y.; Niedernhofer, L.J.; Robbins, P.D. The Clinical Potential of Senolytic Drugs. J. Am. Geriatr. Soc. 2017, 65, 2297-2301. [CrossRef] [PubMed]

104. Amor, C.; Feucht, J.; Leibold, J.; Ho, Y.-J.; Zhu, C.; Alonso-Curbelo, D.; Mansilla-Soto, J.; Boyer, J.A.; Li, X.; Giavridis, T.; et al. Senolytic CAR T cells reverse senescence-associated pathologies. Nature 2020, 583, 127-132. [CrossRef] [PubMed]

105. Wakita, M.; Takahashi, A.; Sano, O.; Loo, T.M.; Imai, Y.; Narukawa, M.; Iwata, H.; Matsudaira, T.; Kawamoto, S.; Ohtani, N.; et al. A BET family protein degrader provokes senolysis by targeting NHEJ and autophagy in senescent cells. Nat. Commun. 2020, 11, 1935. [CrossRef] [PubMed]

106. Mariño, G.; Niso-Santano, M.; Baehrecke, E.H.; Kroemer, G. Self-consumption: The interplay of autophagy and apoptosis. Nat. Rev. Mol. Cell Biol. 2014, 15, 81-94. [CrossRef]

107. Thapa, R.K.; Nguyen, H.T.; Jeong, J.-H.; Kim, J.R.; Choi, H.-G.; Yong, C.S.; Kim, J.O. Progressive slowdown/prevention of cellular senescence by CD9-targeted delivery of rapamycin using lactose-wrapped calcium carbonate nanoparticles. Sci. Rep. 2017, 7, 43299. [CrossRef]

108. Ke, S.; Lai, Y.; Zhou, T.; Li, L.; Wang, Y.; Ren, L.; Ye, S. Molybdenum Disulfide Nanoparticles Resist Oxidative Stress-Mediated Impairment of Autophagic Flux and Mitigate Endothelial Cell Senescence and Angiogenic Dysfunctions. ACS Biomater. Sci. Eng. 2018, 4, 663-674. [CrossRef]

109. Muñoz-Espín, D.; Rovira, M.; Galiana, I.; Giménez, C.; Lozano-Torres, B.; Paez-Ribes, M.; Llanos, S.; Chaib, S.; Muñoz-Martín, M.; Ucero, A.C.; et al. A versatile drug delivery system targeting senescent cells. EMBO Mol. Med. 2018, 10, e9355. [CrossRef]

110. Ekpenyong-Akiba, A.E.; Canfarotta, F.; Abd, H.B.; Poblocka, M.; Casulleras, M.; Castilla-Vallmanya, L.; Kocsis-Fodor, G.; Kelly, M.E.; Janus, J.; Althubiti, M.; et al. Detecting and targeting senescent cells using molecularly imprinted nanoparticles. Nanoscale Horiz. 2019, 4, 757-768. [CrossRef]

111. Musi, N.; Valentine, J.M.; Sickora, K.R.; Baeuerle, E.; Thompson, C.S.; Shen, Q.; Orr, M.E. Tau protein aggregation is associated with cellular senescence in the brain. Aging Cell 2018, 17, e12840. [CrossRef] [PubMed]

112. Riessland, M.; Kolisnyk, B.; Kim, T.W.; Cheng, J.; Ni, J.; Pearson, J.A.; Park, E.J.; Dam, K.; Acehan, D.; Ramos-Espiritu, L.S.; et al. Loss of SATB1 Induces p21-Dependent Cellular Senescence in Post-mitotic Dopaminergic Neurons. Cell Stem. Cell 2019, 25, 514-530.e8. [CrossRef] [PubMed]

113. Salmonowicz, H.; Passos, J.F. Detecting senescence: A new method for an old pigment. Aging Cell 2017, 16, 432-434. [CrossRef] [PubMed]

114. Muñoz-Espin, D.; Demaria, M. Senolytics in Disease, Ageing and Longevity, 1st ed.; Springer Nature Switzerland: Cham, Switzerland, 2020; pp. 163-180.

115. Xu, T.; Cai, Y.; Zhong, X.; Zhang, L.; Zheng, D.; Gao, Z.; Pan, X.; Wang, F.; Chen, M.; Yang, Z. $\beta$-Galactosidase instructed supramolecular hydrogelation for selective identification and removal of senescent cells. Chem. Commun. 2019, 55, 7175-7178. [CrossRef] 
116. Hildebrand, D.; Lehle, S.; Borst, A.; Haferkamp, S.; Essmann, F.; Schulze-Osthoff, K. $\alpha$-Fucosidase as a novel convenient biomarker for cellular senescence. Cell Cycle 2013, 12, 1922-1927. [CrossRef]

117. Lozano-Torres, B.; Blandez, J.F.; Galiana, I.; García-Fernández, A.; Alfonso, M.; Marcos, M.D.; Orzáez, M.; Sancenón, F; Martínez-Máñez, R. Real-Time In Vivo Detection of Cellular Senescence through the Controlled Release of the NIR Fluorescent Dye Nile Blue. Angew. Chem. Int. Ed. 2020, 59, 15152-15156. [CrossRef]

118. Nguyen, H.T.; Thapa, R.K.; Shin, B.S.; Jeong, J.-H.; Kim, J.-R.; Yong, C.S.; Kim, J.O. CD9 monoclonal antibody-conjugated PEGylated liposomes for targeted delivery of rapamycin in the treatment of cellular senescence. Nanotechnology 2017, 28, 095101. [CrossRef]

119. Nagesh, P.K.B.; Chowdhury, P.; Hatami, E.; Kumari, S.; Kashyap, V.K.; Tripathi, M.K.; Wagh, S.; Meibohm, B.; Chauhan, S.C.; Jaggi, M.; et al. Cross-Linked Polyphenol-Based Drug Nano-Self-Assemblies Engineered to Blockade Prostate Cancer Senescence. ACS Appl. Mater. Interfaces 2019, 11, 38537-38554. [CrossRef]

120. Lewinska, A.; Adamczyk-Grochala, J.; Bloniarz, D.; Olszowka, J.; Kulpa-Greszta, M.; Litwinienko, G.; Tomaszewska, A.; Wnuk, M.; Pazik, R. AMPK-mediated senolytic and senostatic activity of quercetin surface-functionalized $\mathrm{Fe}_{3} \mathrm{O}_{4}$ nanoparticles during oxidant-induced senescence in human fibroblasts. Redox Biol. 2020, 28, 101337. [CrossRef]

121. Galiana, I.; Lozano-Torres, B.; Sancho, M.; Alfonso, M.; Bernardos, A.; Bisbal, V.; Serrano, M.; Martínez-Máñez, R.; Orzáez, M. Preclinical antitumor efficacy of senescence-inducing chemotherapy combined with a nanoSenolytic. J. Control. Release 2020, 323, 624-634. [CrossRef]

Publisher's Note: MDPI stays neutral with regard to jurisdictional claims in published maps and institutional affiliations. 